\title{
O USO DO ANTIGO TESTAMENTO NA CARTA DE PAULO AOS FILIPENSES
}

\author{
Use of the Old Testament in Paul's Epistle to the Philippians \\ WALDECir GONZAGa ${ }^{\mathrm{I}}$ \\ Victor Silva Almeida Filho ${ }^{2}$
}

El uso del Antiguo Testamento en la Carta de Pablo a los Filipenses

\section{Resumo}

O presente artigo considera a Carta de Paulo aos Filipenses como oportunidade de ensino, incentivo e encorajamento; apontamentos distintivos do Apóstolo dos Gentios $(\mathrm{Rm} 11,13)$. Procura pôr em evidência essas características a partir do uso de textos do Antigo Testamento, seguindo o método G. K. Beale, em seu Manual do uso do Antigo Testamento no Novo Testamento, e da obra de R. B. Hays, Echoes of Scripture in the Letters of Paul. A partir do método utilizado para identificar o uso do Antigo Testamento (AT) no Novo Testamento (NT), busca-se saber como o apóstolo Paulo empregou e interpretou as alusóes e ecos dos textos veterotestamentários que marcam e influenciam sua redação. Além disso, busca-se compreender o modo como essas passagens foram vistas por Paulo, como elas contribuíram e influenciaram o apóstolo nos momentos em que a carta foi escrita, diante da realidade da comunidade que a recebeu, fazendo sempre uma releitura desses textos, no cotidiano de sua vida comunitária, a partir da realidade concreta da vida da Igreja de Filipos. Busca-se também examinar com atenção dois pontos: a análise do hino cristológico, em Fl 2,10-11, e a relativa questão sobre a unidade dessa carta tida como autenticamente paulina. Dessa forma, o texto se propóe como um auxiliador na compreensão do uso do Antigo Testamento no Novo Testamento, que maciçamente se dá a partir da LXX e não do Texto Hebraico, como se constata igualmente em todo o Novo Testamento e não apenas para as cartas paulinas.

Palavras-chave: Filipenses; Antigo Testamento; Novo Testamento; Citaçôes; Alusões; Ecos; Carta de Paulo; LXX; Texto Hebraico ; Septuaginta.

1 Pós-Doutorado pela Faculdade Jesuíta de Filosofia e Teologia, Brasil. Doutor em Teologia Bíblica pela Pontifícia Universidade Gregoriana, Italia. Diretor e Professor de Teologia Bíblica do Departamento de Teologia da Pontifícia Universidade Católica do Rio de Janeiro, Brasil. E-mail: waldecir@hotmail.com Currículo Lattes: http://lattes.cnpq. br/9171678019364477

2 Doutorando em Teologia Bíblica na Pontifícia Universidade Católica do Rio de Janeiro, Brasil. Mestre em Teologia com ênfase em Teologia bíblica pela PUC-SP. E-mail: victorsilvafilho@gmail.com, Currículo Lattes: http://lattes.cnpq. br/2809542571482009 


\section{Abstract}

This article considers Paul's Epistle to the Philippians as an opportunity for teaching, incentive and motivation, distinctive contributions of the Apostle to the Gentiles (Rom. 11: 13). Thus, the research highlights these features based on the use of the texts of the Old Testament according to the method developed in G. K. Beale's Manual do uso do Antigo Testamento no Novo Testamento and R. B. Hays' Echoes of Scripture in the Letters of Paul. Following the method used to identify the use of the Old Testament in the New Testament, the article aims at understanding how Paul appropriated and interpreted the allusions and echoes of the ancient texts that left a mark on him and influenced his writing. It also aims at understanding how Paul grasped these passages and how they contributed to and influenced the apostle in the moments when the letter was written. He always re-interpreted those texts, in the everyday life of his community, according to the concrete experience of the life of the Church in Philippi. Finally, it also carefully considers two further things: the analysis of the Christological Hymn (Phil. 2: 10-11) and the issue concerning the unity of the epistle, which is regarded as authentically Pauline. Therefore, the article helps to understand how the New Testament appropriates the Old Testament, basing itself on the LXX and not the Hebrew Bible, which occurs not only in the Pauline epistles, but in the whole New Testament.

Keywords: Philippians; Old Testament; New Testament; Pauline Epistle; Quotations; Allusions; Echoes; Hebrew Text; Septuagint.

\section{Resumen}

Este artículo considera la Carta de Pablo a los Filipenses como una oportunidad para enseńar, alentar y alentar; notas distintivas del Apóstol de los Gentiles (Rom 11,13. Busca resaltar estas características del uso de textos del Antiguo Testamento, siguiendo el método G. K. Beale en su Manual de uso del Antiguo Testamento en el Nuevo Testamento, y de la obra de R. B. Hays, Ecos de las Escrituras en las Cartas de Pablo. Es por el método utilizado para identificar el uso del Antiguo Testamento (AT) en el Nuevo Testamento que el apóstol Pablo empleó e interpretó las citas, alusiones y ecos de los textos del Antiguo Testamento que marcan e influyen en su escritura, en el cotidiano de su vida comunitaria, basada en la realidad concreta de la vida de la Iglesia de Filipos. Además, busca comprender la forma en que Pablo vio estos pasajes, cómo contribuyeron e influyeron en el apóstol en el momento en que se redactó la carta, dada la realidad de la comunidad que la recibió, releyendo siempre estos textos. Todavía se examinan cuidadosamente dos puntos: el análisis del himno cristológico en Filipenses 2:611 y la pregunta relativa sobre la unidad de esta carta que se considera auténticamente paulina. Por lo tanto, el texto pretende ser una ayuda para comprender el uso del Antiguo Testamento en el Nuevo Testamento, que proviene masivamente de la LXX y no del texto hebreo, como se ve igualmente en todo el Nuevo Testamento y no solo para las letras paulinas.

Palabras clave: Filipenses; Antiguo Testamento; Nuevo Testamento; Citas; Alusiones; Ecos; Carta de Pablo; LXX; Texto Hebreo; Septuaginta. 


\section{Introdução}

A Carta aos Filipenses foi escrita por Paulo 3 , provavelmente a partir de Roma, nos primórdios da década de 60 d.C., endereçada aos cristãos que estavam em Filipos, comunidade fundada por ele. Essa cidade era considerada um posto avançado de Roma no planalto interior da Macedônia Oriental (Fee, 2004, p. 33). Ela possui poucas referências ao AT, não contendo citaçóes explícitas e sim apenas alusóes implícitas, como veremos ao longo deste nosso ensaio. Diante disso, é preciso se perguntar até que ponto Paulo usou o AT em suas cartas e, mais especificamente, na Carta aos Filipenses. Ainda, é importante se interrogar: e que medida o AT e o NT se relacionam? O que se nota é que o NT traz, em seus livros, ampla gama de citaçôes, alusôes e ecos do AT, embora alguns livros tragam mais e outros menos. Um aspecto interessante da constatação de que realmente temos citações do AT no NT é que, com isso, é possível ver o quanto os autores do NT consideravam o AT como Escritura Sagrada, inspirada e divina, ou seja, como normativa para a vida diária no relacionamento entre os irmáos e com Deus.

Nossa intenção não é fazer um estudo sobre a carta em si, mas sim sobre as alusões do AT que podemos encontrar nela. Também é importante ter presente que nem sempre é fácil identificar e distinguir suas diferenças (Silva, 2008, p. 81), sobretudo quando analisamos as três possibilidades do uso do AT no NT, ou seja: citações, alusões e ecos. Vários são os autores que tratam da temática, mas usaremos sobretudo as obras de Beale e de Hays, que indicaremos ao longo de nosso texto, uma vez que são as obras principais usadas para os critérios e passos a serem trilhados a fim de se encontrar e distinguir as citaçóes, alusões e ecos do AT no NT.

O presente ensaio, com sua análise, não tem a intenção de esgotar o assunto, mas busca, igualmente, iluminar a temática do uso do AT no NT, não obstante o foco principal seja a Carta aos Filipenses, a partir de bibliografias que consideram o seu tema. Em seguida, tece consideraçóes sobre o uso do AT no NT a partir da LXX, fonte onde os autores do NT majoritariamente recorreram para usar o AT. A partir disso, demonstra o uso do AT na carta de Paulo aos Filipenses, mais especificamente sua incidência nos versículos 1,$19 ; 2,10-11 ; 2,15$, nos quais mais notoriamente se percebe a presença do AT na carta paulina, ainda que seja no formato de alusão e não de citação explícita. Nesses trechos, o autor se vale de tal recurso para fundamentar sua narrativa. Por fim, também procuramos trazer algumas notas de rodapé que nos ajudam a problematizar, ou melhor, a entender a temática a partir dos diversos autores.

3 A autoria paulina é fato indiscutível entre os estudiosos. O que se questiona, por exemplo, é a presença de expressôes

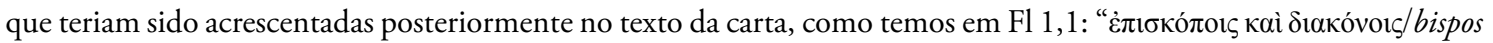
e diáconos", que é um linguajar mais tardio e que teria sido acrescentado ao longo da caminhada dos primórdios da vida da igreja (Craddock, 1985, p. 16). 


\section{0 método do uso do Antigo Testamento no Novo Testamento}

O ponto de partida da pesquisa sobre o uso do Antigo Testamento no Novo Testamento se situa em identificar quais textos o NT cita ou se refere ao AT. Por isso, faz-se necessário definir o que é citação e o que é alusão, e quais são os critérios usados para confirmar uma citação ou alusão (Beale, 2013, p. 53) .

Para Beale, a citação é a reprodução direta de uma passagem do AT facilmente identificada por seu paralelismo vocabular claro e com traços característicos, explicitamente comparável. Parte dessas citaçóes são iniciadas por uma fórmula indicadora: "para que se cumprisse o que o Senhor havia falado pelo profeta" (Mt 2,15), "está escrito" (Rm 3,4), ou uma expressão semelhante. Outras passagens sem tais indicadores prévios apresentam paralelos tão óbvios com algum texto do AT que só podem se tratar de citação (p. ex.: Gl 3,6; Ef 6,3) (Beale, 2013, p. 53).

Já alusão é alvo de intenso embate acerca de sua definição e dos critérios para identificá-la. Alusão pode ser definida como uma expressão breve deliberadamente pretendida pelo autor para ser de uma passagem do AT, que encontramos de forma implícita. Diferentemente da citação do AT, que é uma referência direta, a alusão faz uma referência de modo indireto. A chave para identificar uma alusão consiste em notar se existe um paralelo incomparável ou único de redação, sintaxe, conceito ou conjunto de motivos na mesma estrutura redacional (Beale, 2013, p. 55-56).

Existem alguns critérios que são indicadores para se confirmar a presença das citaçóes, alusóes e ecos no texto bíblico. Segundo Richard B. Hays, em sua obra Echoes of Scripture in the Letters of Paul (1989, p. 29-32), são sete atributos: 1) disponibilidade, se o autor e os destinatários tiveram ou não acesso direto à fonte hebraica ou à fonte grega; 2) volume, qual é o grau de repetição de palavras ou padróes sintáticos no texto precursor e na alusão neotestamentária; 3) recorrência, é necessário analisar a existência de referências ao texto aludido ou ao contexto veterotestamentário usado; 4) coerência temática, até que ponto a suposta alusão se adapta à linha argumentativa desenvolvida pelo autor do Novo Testamento; 5) plausibilidade histórica, em vista de se constatar em que medida é plausível a afirmação de que o autor do Novo Testamento usou a alusão para conseguir um determinado efeito de sentido ressonante nos leitores da época; 6) história da interpretação, constatar se outros autores e leitores foram capazes de perceber as mesmas referências que teriam percebido os contemporâneos do escrito; 7) satisfação, após os seis itens anteriores, ainda é necessário se perguntar se faz sentido a sua utilização em seu contexto imediato, se esclarece e aumenta o vigor retórico da argumentação.

Esses sete critérios para a confirmação do emprego de citações, alusóes e ecos do Antigo Testamento no Novo Testamento, fornecidos por Richard B. Hays, são retomados por Gregory K. Beale, em sua obra Manual do uso do Antigo Testamento no Novo Testamento. Exegese e Interpretação (com tradução e publicação no Brasil), no qual são descritos nove passos (2013, p. 57-58) para a análise das citaçóes, alusóes e ecos do Antigo Testamento no Novo Testamento ampliando ainda mais os pontos da pesquisa em vista da proposta

inicial de Hays. E sua obra, Beale propóe seus nove passos para se trabalhar o uso do Antigo Testamento

4 Além da relação histórica entre ambos os Testamentos, também é importante examinar a relação e o âmbito teológico de ambos, sem contar aspectos culturais, literários e linguísticos da época e o contexto de cada escrito (Robertson, 1996, p. 11). 
no Novo Testamento: 1) identificação e validação da referência ao Antigo Testamento: citação, alusão ou eco, no qual são retomados os sete critérios de Hays, e os demais são propostos por Beale); 2) análise do contexto geral do Novo Testamento em que ocorre a referência ao Antigo Testamento; 3) análise do contexto imediato e do contexto geral do Antigo Testamento, para interpretar atenta e minuciosamente, sobretudo o parágrafo em que a citação ou alusão ocorre; 4) pesquisa quanto ao uso do texto do Antigo Testamento no judaísmo anterior e posterior que possa ser importante para a apropriaçáo do texto veterotestamentário pelo Novo Testamento; 5) comparação dos textos, inclusive suas variantes textuais: NT, LXX, TM e os Targumim, citaçôes judaicas antigas (MMM, Pseudo-epígrafos, Josefo, Filon); 6) análise do uso textual que o autor faz do Antigo Testamento, para se ver em que tradiçáo textual veterotestamentária o autor se apoia, ou se ele está dando sua versão pessoal, e como isso afeta a interpretação do texto do Antigo Testamento; 7) análise do uso interpretativo, hermenêutico, que o autor faz do Antigo Testamento; 8) análise do uso teológico que o autor faz do Antigo Testamento; 9) análise do uso retórico que o autor faz do Antigo Testamento (2013, p. 69-82).

\section{0 texto Hebraico e o texto da LXX no Novo Testamento}

Para se falar de utilização do texto bíblico Hebraico ou Grego no NT, é necessário saber de qual fonte os autores do NT teriam se valido para suas produções redacionais. Ou seja, é preciso reconhecer o Texto Hebraico, se o Texto Massorético ou outro, e o Texto da Setenta (LXX) como fontes usadas na formulação do NT. Além disso, segundo Robertson (1996, p. 23-28), os autores neotestamentários e Jesus também utilizaram técnicas hermenêuticas judaicas, especialmente o midrás ou comentário do texto bíblico judaico.

Quando falamos de Texto Hebraico, defrontamo-nos com a expressão, já conhecida, Tanak, que é um acrônimo formado pelas letras iniciais dos nomes dos três conjuntos da Bíblia Hebraica (Torah, Nebi 'îm e Ketubim). Isso porque os judeus dividiam e ainda dividem as suas Escrituras Sagradas em três grupos e as classificam em: a) Torah ou Lei, que contém os cinco livros do Pentateuco, cuja palavra designa uma conotação literária e não religiosa ou teológica; b) Nebi 'îm ou Profetas, contendo os oito livros proféticos, divididos entre profetas anteriores (Josué, Juízes, 1 e 2 Samuel e 1 e 2 Reis) e profetas posteriores (Isaías, Jeremias, Ezequiel e o conjunto dos Doze profetas "menores"); c) Ketubîm ou Escritos, que traz os 11 livros do conjunto dos escritos em geral (compreendem os Salmos, Jó, Provérbios, os cinco rolos [Rute, Cântico dos cânticos, Eclesiastes, Lamentaçóes e Ester], Daniel, Esdras-Neemias e Crônicas) (Gonzaga, 2019, p. 276-277; Robertson, 1996, p. 23-24).

No que tange ao Texto Hebraico, é preciso ter presente que Tanak conta com textos dos mais variados gêneros literários, escritos em épocas e por pessoas diferentes. Outra forma de se referir à Bíblia Hebraica, com seus três conjuntos de livros, é o termo Mikra (ארקמ), que tem um tom mais formal do que o termo

5 Midráš se encontra seja na forma de halaká, que trata de argumentos legais e éticos, seja na forma da hagadá, que compreende narraçóes criativas e expandidas das Escrituras.

6 A Tanak corresponde ao AT da Bíblia cristã, exceto os sete livros deuterocanônicos presentes em algumas tradiçóes, como a Católica e Ortodoxa (Tobias, Judite, $1^{\circ}$ e $2^{\circ}$ Macabeus, Sabedoria, Eclesiástico e Baruc); além desses, temos alguns capítulos e versículos a mais em Daniel [3,24-90; 13 e 14] e em Ester [10,4-16,24]). 
Tanak. O cânon da Tanak é composto de 24 livros, que na verdade são 39, visto que temos alguns que são duplos (Samuel, Reis, Crônicas, Esdras e Neemias). Os doze profetas menores são contados como um livro apenas. Além de o número variar, a Bíblia Hebraica contém uma ordem diferente da Bíblia das tradiçôes cristâs, que seguem a ordem da Vulgata de Jerônimo (Gonzaga, 2019, p. 276) ${ }^{7}$.

Até 1947, data de descoberta da primeira caverna de Qumran, nossas ediçóes da Bíblia Hebraica se baseavam apenas no Codex Leningradensis, o qual é o testemunho mais antigo do que se chama "Texto Massorético" (TM), mas hoje contam também com o apoio das variantes de Qumran. Com esse nome, identifica-se uma tradição textual hebraica do AT que foi vocalizada e anotada pelos massoretas. $\mathrm{O}$ texto consonântico recebe o nome de pré ou proto-massorético, o qual deve ter alcançado sua estabilidade e fixação por volta do séc. I ou início do séc. II d.C., fruto de um esforço de unificação de uma tradição textual que devia remontar à época do Segundo Templo (Belli (et al.), 2006, p. 39-40).

Os autores do NT tiveram diante de si essa forma textual pré-massorética, mas, precisamos levar em consideração que esse texto não vocalizado, possivelmente seria análogo, mas não idêntico ao que temos na atualidade, ou seja, ao Texto Massorético (TM). Por meio do testemunho de versóes antigas como Peshita (siríaca) e Vulgata (latina), que são traduzidas a partir de um texto pré-massorético, sabemos que este último era ligeiramente diferente do TM (Belli (et al.), 2006, p. 40).

A Versão Septuaginta (LXX) é a tradução mais antiga da Bíblia Hebraica de que se tem notícia. Ela contém a tradução do hebraico e do aramaico para o grego dos livros contidos na Tanak, realizada entre os sécs. III e II a.C., aos poucos, em Alexandria, no Egito. Além disso, a LXX contém os livros chamados de deuterocanônicos do AT, que foram escritos diretamente em grego (Gonzaga, 2019, p. 280) ${ }^{8}$. Os manuscritos mais antigos da LXX são precedentes ao cristianismo, alguns são datados, inclusive, do séc. II a.C. Temos um bom testemunho de toda a Bíblia segundo a Septuaginta apenas no séc. IV d.C., quando são escritos os grandes Códices Unciais (escritos em maiúsculas), quando os cristãos unem num mesmo volume AT e NT em língua grega (Belli (et al.), 2006, p. 42).

Segundo a Carta de Aristeia, um texto apócrifo do AT, a tradução da LXX, que a princípio estava circunscrita ao Pentateuco e posteriormente ampliou sua abrangência, foi uma obra encomendada pelo Rei Ptolomeu II Filadelfo, do Egito, para que ele pudesse ter uma cópia dos textos sagrados em grego na Biblioteca de Alexandria. Segundo a lenda, a obra teria sido executada por 72 judeus instalados na Ilha de Faros, sendo seis de cada uma das 12 tribos de Israel, que teriam trabalhado nela e completado a tradução em 72 dias. Mas para além do mito dessa carta, o importante é que de fato efetuou-se realizou uma obra de tradução dos textos bíblicos do hebraico para o grego, entre os anos 250 a 150 a.C. Desde o séc. I d.C.

7 O cânon e a ordem desses textos foram retirados da obra de K. Elliger e W. Rudolph, Biblia Hebraica Stuttgartensia, 1994, e é texto-base para as traduções da Bíblia para o AT desde que os Massoretas vocalizaram o texto, entre os sécs. VI e VIII da nossa era, e o têm transmitido dessa forma. Dois Códices hebraicos realmente são importantes para o mundo judaico: o Codex de Aleppo (930 d.C.) e o Codex Leningradensis (1008 d.C.). Para F. Belli (et al.) (2006, p. 39-40), a datação da vocalização feita pelos massoretas acontece no período que vai do séc. VI ao X d.C.

8 Haag (1971, p. 119-156) recorda que é preciso levar em consideraçáo que os mais antigos manuscritos que temos da versão LXX são da versão da LXX cristã e não da versão da LXX judaica. Por serem do séc. IV d.C., os manuscritos cristãos podem ter diferenças que até então se desconhece. 
a Septuaginta foi adotada pelo cristianismo de língua grega e utilizada como base para muitas traduçóes antigas, como as versóes latinas, eslavas, armenas, georgianas, coptas, Héxapla de Orígenes, e outras que surgiram posteriormente (Gonzaga, 2019, p. 281; Robertson, 1996, p. 26).

Para o cristianismo, a Septuaginta tem um valor muito grande. É a Bíblia mais citada no NT. De aproximadamente 350 citaçóes do AT no NT, 300 são da versão LXX e apenas 50 são da Tanak. Ainda, é considerada de igual valor pelos Padres da Igreja, tanto orientais como ocidentais, sendo que seus Códices mais antigos datam dos sécs. IV-V d.C., a saber: Vaticanus, Sinaiticus e Alexandrinus (Gonzaga, 2019, p. 282).

No exercício de uma crítica textual adequada a LXX, é tarefa fundamental para o estudo de outras versôes antigas surgidas dessa tradução, em especial a Vetus Latina ou Vetera Latina, que se trata da tradução ao latim de um tipo textual da LXX tal como circulava em torno do séc. II d.C. (Belli (et al.), 2006, p. 43). Além disso, precisa ser considerado o vastíssimo número de outros Manuscritos contidos na Septuaginta, desde o séc. I a.C. até o período cristáo. Ela não acompanha a Bíblia Hebraica para a nomenclatura dos livros nem para sua ordem ou classificação, que obedece a um critério próprio, e que será seguido posteriormente pela Vulgata e pelos cristãos em geral, no que se refere à ordem dos textos nas bíblias modernas (Gonzaga, 2019, p. 281-282). Enfim, após ter discorrido sobre o texto do AT (hebraico e grego), é importante fazer a análise de sua presença dentro da Carta aos Filipenses, procurando ver qual fonte Paulo teria usado e se isso se deu por citação, alusão ou eco das Escrituras veterotestamentárias.

\section{A Carta aos Filipenses}

A maioria dos estudiosos aceita que a Carta aos Filipenses é um escrito autenticamente paulino (Gonzaga, 2017, p. 22; Craddock, 1985, p. 16). Ela caracteriza-se por um tom afetuoso. Entre suas comunidades, a de Filipos ${ }^{9}$ era uma que Paulo muito apreciava ${ }^{10}$. Era a primeira da sua missão em território europeu, onde converteu e batizou Lídia (At 16,11-15). Mas, também é uma carta que apresenta graves problemas no plano da crítica histórica e literária. A discussão não fica presa apenas sobre o local e ano de sua redação, mas recai sobre a temática da unidade literária. Aqui é preciso distinguir a questáo da "integridade" e da "autenticidade". Quando se refere à integridade se menciona o documento enviado por Paulo aos filipenses

9 A cidade de Filipos foi fundada pelo rei Filipe II, pai de Alexandre Magno, em meados do séc. IV a.C., como sua cidade residencial. Era considerada uma "mini-Roma” no Leste. Por causa de sua localização favorável para o tráfego de ricas minas de ouro e prata, floresceu rapidamente. Depois que a Macedônia foi incorporada ao Império Romano, Filipos tornou-se colônia militar, Colonia Augusta Julia Philippensis, detentora do ius Italicum, o direito romano. Era atravessada pela estrada comercial entre Europa e Ásia (a Via Egnatica), o que inseria a cidade no contexto de comércio ativo. Não causa surpresa que, numa colônia romana tão autoconsciente, os judeus continuassem sendo poucos, a ponto de nem mesmo conseguirem estabelecer uma sinagoga própria (At 16,13.20-21). Por essa razão, as tribulaçóes que a Igreja teve de suportar aqui não devem ter partido de judeus, mas devem ter preservado o caráter "antissemita" dos primeiros conflitos, Hahn e De Boor, 2006, p. 176; Barbaglio, 1991, p. 353.

10 Certamente, em nítido contraste com outras cartas, como Gálatas e Romanos, os propósitos de Paulo não se concentram em questóes controversas da interpretação das escrituras: o tom cordial dessa carta assume uma harmonia teológica e hermenêutica entre Paulo e seus leitores (Hays, 1989, p. 21; Pastor, 2009, p. 59). 
na sua originalidade. Isso incide na questão que alguns estudiosos têm levantado a respeito da composição e da unidade da carta tal como a temos hoje, se forma um todo unitário ou se é fruto da união de vários textos. Há indícios, dentro da própria carta, que justificam que se trata de uma compilação, primeiro agrupada e, mais tarde, publicada, não por Paulo, mas por outra pessoa (Martin, 2011, p. 23). Quando se menciona a autenticidade, procura-se verificar quanto da carta, quer seja uma unidade ou compilação, é genuinamente de Paulo (Martin, 2011, p. 23) ${ }^{11}$. A maior parte dos estudiosos, mesmo os que julgam Fl 3,1-4,1 um fragmento interpolado, acredita ser uma carta paulina (Gonzaga, 2017, p. 22). O hino de Fl 2,6-11, segundo alguns autores, pode ser anterior a Paulo, que o teria tomado, e possivelmente editado e feito uma inclusão na carta (Martin, 2011, p. 24; Holloway, 2017, p. 16-24; Etcheverría, 2002, p. 259), mas esse é um tema ainda e sempre em discussão. O gênero literário da Carta aos Filipenses é um fenômeno complexo que levanta questóes de forma, conteúdo e propósito. Porém, essa carta é considerada no meio acadêmico como uma "carta de consolação". A análise do gênero literário permite que os intérpretes das cartas de Paulo identifiquem outros materiais antigos que podem servir como fontes legítimas de comparação (Holloway, 2017, p. 31-34) ${ }^{12}$.

Quanto ao local de sua redação, três teorias tentam definir a época com base no lugar, e vice-versa, podem ser alinhavadas sob os títulos: Roma (redação entre 60-63 d.C.), Cesaréia (redação entre 58-60 d.C.) e Éfeso (redação entre 54-57 d.C.). Segundo uma antiga tradição a Carta aos Filipenses é originária da época do cativeiro em Roma, provavelmente onde Paulo passou maior tempo preso. Além disso, as observaçóes

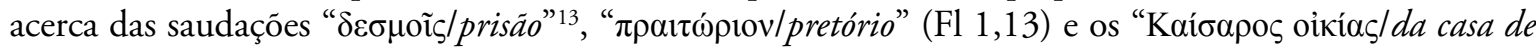
César" (Fl 4,22) fazem convergir numa tendência para que se tome a decisáo de considerar Roma como local redacional. A hipótese que tem Éfeso como local redacional coloca novos pontos de vista no debate. Éfeso era próxima de Filipos, o que facilitaria um rápido deslocamento. Aqueles que defendem Cesaréia consideram essa possibilidade a partir da parte final do cativeiro em Roma, argumento considerado débil e ignorado por muitos (Hahn e De Boor, 2006, p. 163-167; Hawthorne, 2008, p. 556-564; Hendriksen, 2005, p. 376-378).

11 Martin desenvolve essa questão da autenticidade da Carta aos Filipenses colocando de um lado uma opinião de cunho mais desregrado, segundo a qual a carta toda não é paulina (Bauer, 1875, p. 45-79), e de outro lado, uma apreciação mais moderada (Weiss, 1959 , p. 386ss), segundo a qual alguns fragmentos não provieram das mãos de Paulo, como Fl 2,6-11 que, acredita-se de modo geral, que seja um hino pré-paulino que Paulo incorporou à sua carta. Etcheverría (2002, p. 259-260) também trilha essa mesma linha de raciocínio, ao defender a atribuição pré-paulina do hino de Fl 2,6-11; porém, geralmente, ele o faz baseado em uma série de dados considerados insuficientes. O mais curioso é a mesma identificação pré-paulina, por Etcheverría atribuída aos textos de Fl 3,20-21 e 1Cor 8,6. No entanto, não é surpreendente que existam divergências entre diversos autores sobre esses elementos.

12 Para Holloway, o fato de Filipenses ser entendida como carta de consolação repousa sobre a intepretação que ela teve junto aos estudiosos cristãos da Antiguidade, como Crisóstomo, Teodoreto e Jerônimo.

13 O termo grego usado para "prisóes" evoca as correntes com as quais se prendiam os prisioneiros, aparece nos versículos de Fl 1,7.13.14.17. Foi isso que levou a carta a ser contada entre as "cartas do cativeiro". Aqui a reflexão de Paulo é que ele está encarcerado, mas o Evangelho continua livre e sendo anunciado. E mais: a prisão de Paulo é motivo para que a Palavra seja anunciada ainda com maior destemor (Hendriksen, 2005, p. 378). 


\section{0 uso do AT na Carta aos Filipenses}

Segundo a metodologia do uso do AT no NT, acima apresentada, busca-se neste item a identificação e a comparação dos textos do AT aludidos na Carta aos Filipenses, tendo como fonte os textos da LXX. A princípio, a Carta aos Filipenses não mostra um interesse especial pelos textos das Escrituras do AT, ou seja, o AT ${ }^{14}$. Conforme nos indica Silva (2008, p. 78), em sua tabela de citaçóes do AT nas cartas paulinas, de fato, não encontramos nenhuma citação explícita nessa carta. Todavia, Paulo oferece elementos dignos de atenção nesse campo, pois retoma com certa fidelidade a terminologia de alguns textos do AT, como podemos conferir em Fl 1,19 (=Jó 13,16); Fl 2,10-11 (=Is 45,23) e Fl 2,15 (=Dt 32,5). Essas referências, como indicado no item sobre o método do uso do AT no NT, não podem ser consideradas citaçóes e, de fato, não se desenvolvem como tais. Porém a reprodução fiel à terminologia do AT nela encontrada, indica uma dependência voluntária ao texto do AT no nível da alusão (Belli (et al.), 2006, p. 200; Hays, 1989, p. 21-24; Reumann, 2006, p. 189-200).

Outro aspecto a ser sublinhado é o do contexto bíblico do hino paulino de Fl 2,6-11. Em particular, parece existir duas figuras implícitas na apresentação cristológica desse texto: a de Adão como "imagem de Deus" e, sobretudo, a do "servo sofredor" de Is 53, em seus aspectos de humilhação e exaltação. Nesse sentido, o conteúdo da carta, em sua perspectiva comunicativa, não exige uma referência explícita. Pelo contrário, o fato de se fazer alusão em termos e/ou figuras bíblicas, demonstra que os destinatários tinham familiaridade suficiente com os textos do AT para reconhecê-los e isso mostra que a exortação e o anúncio cristáos estão enraizados na tradição das Escrituras de Israel (Belli (et al.), 2006, p. 201).

a) em Fl 1,19, Paulo faz alusão a Jó 13,16 no texto referente à LXX (Hawthorn e; Martin, 2004, p. 49) ${ }^{15}$. Esse trecho, raramente tratado na crítica literária paulina sobre o uso do AT, permite-nos examinar seu uso literário como alusão às Escrituras do AT, tendo em vista que este não foi um locus theologicum frequentado por nossos precursores acadêmicos (Hays, 1989, p. 21). No v.19, Paulo assegura aos filipenses que: "através de suas oraçóes e da ajuda do Espírito de Jesus Cristo, isto resultará em minha salvação ${ }^{16}$."

14 É verdade que há alguns elementos doutrinais presentes, de modo especial na cristologia de Fl 2,6-11, e, em algumas ocasiōes, as advertências contra as falsas doutrinas ou avisos sobre comportamentos a serem evitados (Fl 3,2-5) (Belli (et al.), 2006, p. 201).

15 Segundo Fee (2004, p. 185-186), para analisar a explicação de Paulo devemos iniciar com um fenômeno literário denominado "intertextualidade", interpolaçáo consciente em um texto de fragmentos de outro anterior. Isso revela um Paulo "impregnado" por uma vida espiritual e teológica das realidades do AT.

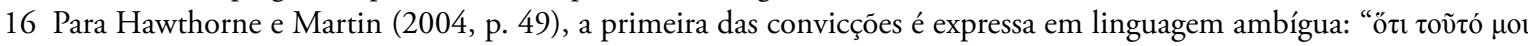

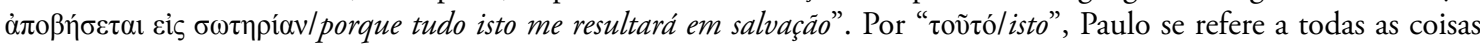
ocorridas com ele, boas e ruins, "perplexidades e aborrecimentos", e assim por diante, que vieram a ele como resultado da pregação do Evangelho. $\Sigma \omega \tau \eta$ pía é uma palavra especial no vocabulário paulino. Paulo a usa para se referir à Salvação suprema que as pessoas experimentarão no último julgamento (Rm 1,16;10,10;13,11;2Cor 7,10; 1Ts 5,8-9; 2Ts

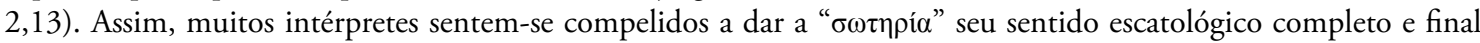
aqui. Eles insistem que Paulo quer dizer que ele está confiante de que perseverará até o fim e, portanto, será salvo no dia de Cristo. $\Sigma \omega \tau \eta \rho$ pí também tem um significado voltado para o campo semântico de "saúde" ou de "bem-estar". 


\begin{tabular}{|c|c|c|c|}
\hline Fl 1,19 - NT & Tradução & Jó 13,16 - LXX & Comentário \\
\hline 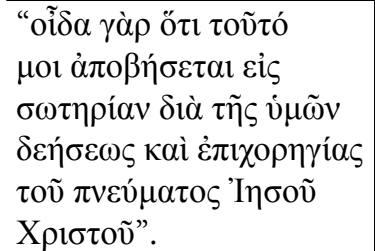 & $\begin{array}{l}\text { "Pois sei que isto me } \\
\text { resultará em minha } \\
\text { salvação por meio de } \\
\text { vossa súplica e pela } \\
\text { assistência do Espírito } \\
\text { de Jesus Cristo". }\end{array}$ & 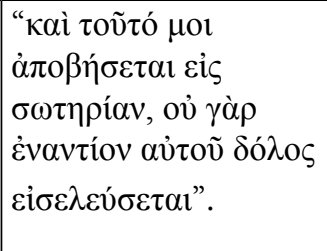 & $\begin{array}{l}\text { Conforme exposto, a alusão } \\
\text { faz alusão ou eco à passagem } \\
\text { de um Jó, confiante na } \\
\text { intervenção divina por meio } \\
\text { das oraçốes dos filipenses. }\end{array}$ \\
\hline
\end{tabular}

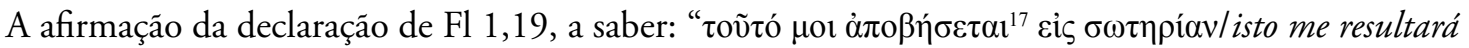
em salvação", embora não precedido por uma fórmula, é uma ressonância das palavras retiradas de Jó 13,16, segundo o texto da LXX: " $E$ isto resultará em salvação para mim, pois diante dele o engano não aparecera". O eco é efêmero e a sentença de Paulo é totalmente compreensível para um leitor que nunca ouviu falar de Jó. Um leitor alimentado pela LXX pode, tranquilamente, apontar a alusão a Jó 13,16. Mas é capaz também de localizar a fonte da "voz" original e suas intrigantes ressonâncias. Dessa forma, entre a situação de Jó e de Paulo, cria-se um importante processo hermenêutico de intertextualidade, no qual o primeiro esclarece e ilumina o segundo (Hays, 1989, p. 23; Reumann, 2008, p. 238; Pitta, 2010, p. 92; Reumann, 2006, p. 189-190).

Paulo, possivelmente aguardando seu julgamento, ecoa na voz de Jó a afirmação de sua confiança no resultado favorável de suas afliçóes, mesmo que implicitamente, transferindo a si próprio aqueles tormentos e amarguras que tradicionalmente estavam relacionadas a Jó. De fato, uma apreciação completa do efeito da alusão ou do eco pode levar o leitor a refletir não apenas nas correspondências entre Paulo e Jó, mas também nos contrastes: enquanto Jó suportava seu sofrimento com perplexidade obstinada, observando-o como se estivesse diante de um vidro opaco, Paulo, sofrendo como apóstolo de Cristo, interpreta seu sofrimento como uma participação no sofrimento do Cristo crucificado, como faz em outras de suas cartas, e, assim, vê-se capaz de se alegrar em meio às adversidades. A afirmação tenaz de Jó de sua própria retidão se torna na boca de Paulo uma afirmação triunfante de confiança no poder e na fidelidade do Deus que ressuscitou Jesus dentre os mortos. (Hawthorne e Martin, 2004, p. 49; Reumann, 2008, p. 232; Pastor, 2009, p. 71) ${ }^{18}$.

Na perspectiva da Análise Retórica (Meynet, 1993, p. 391-408; Meynet, 1996, p. 403-436), o v.19 se insere na unidade da perícope de Fl 1,12-26, trecho conhecido como "tentaçóes de Paulo". Porém, as

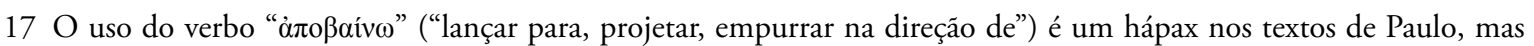
confere um sentido especial a eles. A certeza da Salvação, não procede dos sofrimentos ou hostilidades sofridas, mas da ação de Deus em favor de seus servos, pois do jeito que tratou seu filho, Jesus Cristo (Fl 2,9-11), trataria também aqueles que encarnariam seu estilo de vida e missáo (Mazzarolo, 2011, p. 61-62). Para Reumann (2006, p. 189), o uso das palavras do AT em Filipenses tem em vista o fato de que estão embutidas por esse uso e, por isso, não estão sinalizadas por uma fórmula e, portanto, são mais difíceis de serem detectadas.

18 Para Hays (1989, p. 22) há diferenças entre cada uma das situaçôes em questâo: Jó e Paulo. A maior diferença diz respeito à posição deles em relação a Deus: Deus parece ser adversário de Jó na questão por ele vivida, atribuindo-lhe a injustiça, ao menos temporariamente. Paulo, contudo, vê Deus como seu próprio defensor, não como seu adversário. Isso não o impede, no entanto, de descobrir na linguagem de Jó o retrato de sua própria situação. Paulo tem a plena certeza de que Cristo será engrandecido e glorificado por meio de sua pessoa, que, no momento da carta, está em uma situação bastante negativa. Essa glorificação não é explícita, mas é bem possível que outros reconheçam a ação do próprio Jesus no modo de viver e / ou de morrer de Paulo (Pastor, 2009, p. 71). 
propostas macroquiásticas (de sua grande estrutura quiástica) em Filipenses diferem consideravelmente entre si e, por isso, não fornecem base convincente para interpretação. Alguns estudiosos vinculam 1,19 ao conjunto literário das chamadas "tentações de Epafrodito" (Fl 2,19-30), e isso tem alguma plausibilidade; ambas as passagens são importantes e expressivas: ameaça de morte $(1,21-23 ; 2,27)$, a esperança, a experiência da libertação e da misericórdia de Deus (Reumann, 2008, p. 233). A proposta macroquiástica para Fl 1,19-26 se apresenta, então, da seguinte forma: envolve "vida" e "morte"; o v.21b, "morrer", faz paralelo com "partir", do v. 23; o v.22, "viver na carne", é homeomorfo a "permanecer na carne", do v.24; o v.22, "fruto para o meu trabalho", corresponde a "por vossa causa", do v.24; o v.23, "estar com Cristo", faz uma identificação retórica com "viver (é) Cristo", do v.21a. No mínimo, é uma antítese, talvez em estilo de diatribe (Reumann, 2008, p. 233-234), como é comum encontrarmos em textos paulinos. Além disso, é importante que tenhamos claro que o emprego da retórica permite a Paulo comunicar-se de forma mais argumentativa e isso é programático no Apóstolo (Aletti, 2011, p. 71).

João Crisóstomo lê Fl 1,19 a partir da dinamicidade da força das orações e ação divina do Espírito Santo: "Olhe na humildade deste santo: nos combates era lutador, inumeráveis seus feitos, depois ele foi premiado com sua própria coroa. De fato, este era Paulo: O que se poderia dizer? Ele até escreve para aos filipenses: 'Pela vossa oração posso ser salvo'; ele, que havia ganhado a salvaçáo por inúmeras boas açóes" (Rodriguez, 2001, p. 281-282).

b) em Fl 2,10-11, Paulo faz um paralelo com o texto de Is 45,23, segundo da LXX, onde Deus diz uma

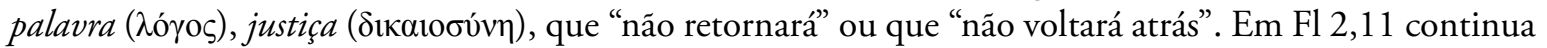
o paralelismo tendo como ponto de apoio o mesmo texto de Isaías da Septuaginta, usando "confesse", que alguns traduzem por "reconheça" ou "jure", para se referir ao termo que na LXX é غ̇ं (Reumann, 2008, p. 358-377; Fee, 2004, p. 292; Grappe, 2013, p. 31) ${ }^{19}$.

\begin{tabular}{|c|c|c|c|}
\hline Fl 2,10-11 - NT & Tradução & Is $45,23-\mathrm{LXX}$ & Comentário \\
\hline 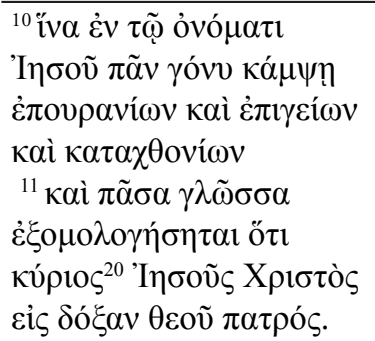 & $\begin{array}{l}{ }^{10} \text { para que ao nome de } \\
\text { Jesus todo joelho se } \\
\text { dobre, nos céus, na terra e } \\
\text { debaixo da terra, } \\
{ }^{11} \text { e toda língua confesse } \\
\text { que Jesus Cristo é Senhor, } \\
\text { para glória de Deus Pai. }\end{array}$ & 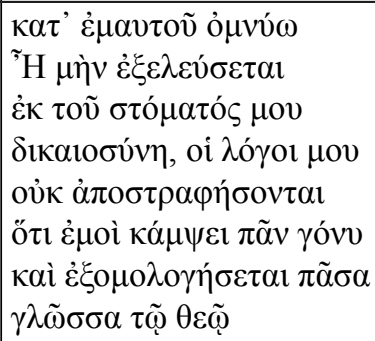 & $\begin{array}{l}\text { Fica marcada a diferença } \\
\text { da alusão ou eco que } \\
\text { Paulo faz de Isaias: há uma } \\
\text { ênfase paulina em declarar } \\
\text { abertamente em Jesus } \\
\text { um caráter divino, o que } \\
\text { desafiaria frontalmente o } \\
\text { culto imperial ao imperador. }\end{array}$ \\
\hline
\end{tabular}

19 Para Reumann (2008, p. 358-377), o texto de Isaías, na versão da LXX, relata e enfoca a justiça salvadora e justificadora de Deus, embora alguns sejam envergonhados. Paulo reescreve em Fl 2,10-11 e apresenta o triunfo de Deus, em Cristo, sobre o Império romano.

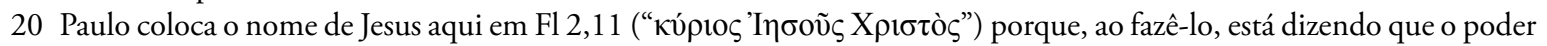
"nobre" foi colocado "nas mãos" da pessoa histórica de Jesus de Nazaré, que não é uma cifra cósmica ou governante despótico, mas uma figura a quem os cristáos poderiam dar um rosto e um nome. Ele está falando daquele que se esvaziou, que se humilhou, que se tornou humano no espaço e no tempo, que se tornou escravo, que foi crucificado, que sofreu morte de um criminoso. $\mathrm{Na}$ Antiguidade era comum as pessoas acreditarem em um universo de três andares 


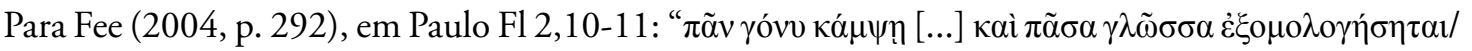

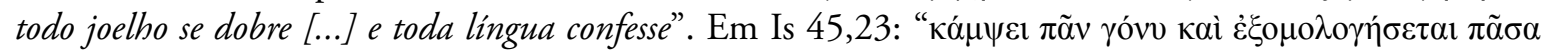
$\gamma \lambda \tilde{\omega} \sigma \sigma \alpha /$ se dobre todo joelho e confesse toda lingua”. Possivelmente, Paulo (séc. I) teria citado um texto ancestral, um hipotético texto-tipo Alexandrino (séc. IV), porém, com uma transposição de " $\pi \tilde{\alpha} \sigma \alpha \gamma \lambda \tilde{\omega} \sigma \sigma \alpha$ $\grave{\varepsilon} \xi o \mu$ o

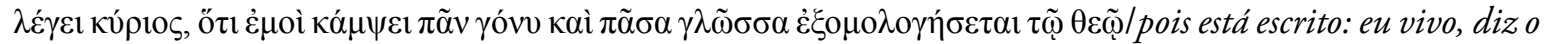
Senhor, diante de mim se dobrará todo joelho e toda lingua confessará a Deus"), ratificando, dessa forma, uma leitura por ele conhecida e não de uma narrativa por ele criada. Além disso, a transposição, embora varie um pouco, textualmente falando, nos faz pensar, por um lado, que Paulo deve estar citando de memória e, por outro, o Códice Alexandrino também não significa e nem pode ser considerado uma adaptação paulina de forma livre. O mais provável é que Paulo conhecesse o texto de Is 45,23 a partir de algumas versões, inclusive do texto hebraico. Porém, isso não impede que haja vários ecos verbais evidentes por meio de expressóes paralelas (Focant, 2016, p. 156).

A importância não apenas de Fl 2,10-11, mas de todo o hino cristológico, Fl 2,6-11, cresceu ao longo dos séculos de cristianismo, porém suas origens em Filipos são obscuras. Somente um apóstolo inspirado poderia escrever tão belo trecho que ressoaria aos ouvidos dos filipenses como um modelo de volta às raízes da fé cristã na tradição veterotestamentária, quem sabe de uma Igreja de língua aramaica, mais próxima do próprio Jesus, e fornecer bases para uma cristologia posterior (Reumann, 2008, p. 377) ${ }^{21}$. Neste sentido, uma alusão ou um eco, feito por Paulo, do texto de Isaias teve por objetivo fazer com que seus leitores centrassem suas vidas em Cristo, tendo-o como paradigma e regra normativa. Seu objetivo era levar ânimo aos filipenses, e aos leitores de todas as épocas, a fim de que colocassem seus olhos em Cristo e seguissem seu modelo de entrega, amor e sacrifício. Serve de exemplo para a vida presente no Espírito, enquanto

e, portanto, seu espaço abrangente era geralmente expresso por frases que compreendiam todas as três partes, assim se

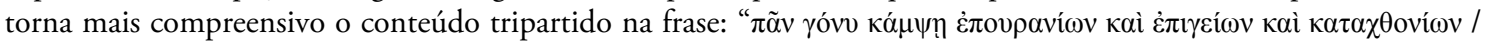
todo joelho se dobre, nos céus, na terra e debaixo da terra” (Fl 2,10) (Hawthorne e Martin, 2004, p. 127-128).

21 Segundo Focant $(2016,157-158)$, há ao menos três razóes para a redação do hino cristológico de Filipenses que não impóem como dependência literária precisa, enquanto textos com fundamentaçáo e enraizamento no mundo bíblico judaico que poderiam ter influenciado Paulo a ter dado seu louvor a Cristo: 1) a figura temática do Servo sofredor (Is 52,13-53,12), amplamente reconhecida pela crítica, inclusive com certa dependência literária; 2) a oposição entre o $1^{\circ}$ e o $2^{\circ}$ Adão, temática encontrada em Rm 5,18-19 e em 1Cor 15,45-47: Adão caiu na armadilha de querer ser como Deus (Gn 3,5), e Cristo, o segundo Adão, renunciou num movimento de kénosis, e, ao final, recebeu gratuitamente a glória divina; 3) uma crítica aos reis que usurpavam a dignidade divina. Entretanto, nenhuma das razóes anularia a originalidade do louvor, que não se reduz a nenhuma dessas influências. Para um estudo específico do hino cristológico de Fl 2,5-11 sugerimos a leitura das obras de: Grappe, 2013; Pitta, 2010; Ueti, 2010, p. 57-75. Fitzmyer (1988, p. 470-483) reconhece alguns problemas na acentuação de palavras e na estrutura do hino, seja em grego, seja na protoversão aramaica. Ele propóe o hino na composiçáo de 18 linhas simples distribuídas em duas estrofes de três versículos trilineares. Por isso, ele entende esta perícope como uma composição retórica pré-paulina de origem judaicocristã. Murphy-O’Connor (2006, p. 25-50) dá uma explicação centrada exclusivamente em Sb 2,23. Ele alega que a partir da história da exegese este hino ficou marcado pela ótica da preexistência. Somente a teoria do Servo e do Justo Sofredor é, por sua vez, insuficiente para dar conta de todos os dados do hino. Humildade e obediência (2,7c-8) são as características sobressalentes do Servo (Is 53,8 LXX) e do Justo (Sb 6,17-18). Em ambas passagens aparece o esquema de humilhação e exaltação (Is 52,13; Sb 3,8). 
que ao final teremos com ele a glória escatológica e a "forma" que Cristo já tem no presente, sendo "tudo isso para a glória de Deus Pai” (Fee, 2004, p. 296-298) ${ }^{22}$.

Em meio a inúmeras propostas de estrutura quiástica, os vv.10-11 estão situados no conjunto de Fl 2,6-11, o qual raramente é "quiasticizado". O quiasmo foi reivindicado nos vv.10-11, mas há pouco acordo entre os estudiosos do tema (Reumann, 2008, p. 362). Os Padres da Igreja e outros autores da época Patrística deixaram os seguintes relatos sobre esses dois versículos do hino cristológico: "Cristo é adorado como Deus na unidade de seu ser humano e divino" (Gaudencio de Brescia); "Sua humanidade é penetrada por sua divindade e vice-versa, em virtude da comunicação de propriedades" (Gregorio de Nisa); "Ele, que justamente louvou ao Pai, recebe agora nosso louvor" (Cirilo de Alexandria); "Agora todos os tipos de criaturas o reverenciam. Até espíritos angelicais se prostram metaforicamente" (Orígenes); "Cristo se senta agora como soberano, como o primogênito dentre os mortos" (Gregório de Nisa); "Isto demonstra que Cristo é Deus" (Teodoreto); "O Pai é glorificado mediante a salvação da humanidade" (Atanasio); "Toda língua quer dizer 'todas as naçóes' e o fato de reconhecer o Senhor como Cristo honra o Pai" (Rodriguez, 2001, p. 311). Em todos esses testemunhos, o que se constata é que a glória do Pai é encontrar o Homem que havia sido feito e que estava perdido e dar vida ao que estava morto e convertê-lo em templo de Deus. Mas isso não poderia ter sido realizado se aquele que existia na forma de Deus não tivesse assumido a forma de escravo e se humilhado a ponto de permitir que seu corpo morresse" (Rodriguez, 2001, p. 312313). Aliás, o nascimento de Cristo assumindo toda a condição humana, inclusive em suas precariedades temporais, é uma visão plenamente paulina (Gonzaga, 2019a, p. 1194-1216).

Todo o hino cristológico de Fl 2,5-11, e não apenas os vv.10-11, é realmente um texto-chave para se entender a forma como Paulo vê a Deus. Fica claro que Cristo serve como modelo, mas o faz como aquele que melhor expressa a natureza divina. Sendo Deus, Cristo se despojou de si mesmo, náo buscou seus próprios interesses ou benefícios. Sendo homem, sem deixar de ser Deus, "humilhou-se e se aniquilou até a morte e morte de cruz". Para Paulo, isso define a essência de Deus. Os filipenses, e todos os seguidores de Jesus, não são chamados simplesmente a "imitar Deus" no que fazem, mas são chamados a ter essa

22 Para Fee (2004, p. 298), a preocupação que Paulo tem em Fl 2,6-11 por uma conduta fica refletida nas exortaçôes que aparecem ao longo de toda a carta. O Evangelho de Paulo toma como certo que os que estáo em Cristo se comportam de uma maneira digna do Evangelho de Cristo (Fl 1,27). Portanto, na ética paulina, seu princípio é o amor, o modelo é Cristo, o poder é o Espírito, e seu propósito último, a glória de Deus; e isso está ao nosso alcance graças à morte e ressurreição de Cristo. Segundo Pastor (2009, p. 75-78), Cristo se apresenta a partir de seu modo divino, rebaixa-se à condição humana, chegando aos aspectos mais depreciativos dessa condição, razão pela qual logo é exaltado pelo Pai até à total glorificação. São, de fato, dois movimentos: um descendente (vv. 6-8) e outro ascendente (vv. 9-11). Um justo que sofre e é exaltado por Deus já estava presente em diversos textos do AT, como Sl 22; 49,15-16; Is 52,13-53,12. O sujeito protagonista do hino é Cristo, não exatamente "o Filho", isso tem importância no sentido de que as afirmações não se referem a um ser divino em si, mas àquele que assumiu a forma humana. O título "кúptoç/Senhor", constitui a síntese do reconhecimento para com a pessoa de Jesus; ele é a fórmula de fé tradicional da comunidade primitiva. Nesse contexto, também ressoa a maneira de se mencionar da tradiçáo grega da Setenta, que usou o termo kúpıs para traduzir o Tetragrama Sagrado: YHWH. Além disso, todas as evidências indicam que a afirmação "Jesus Cristo é o Senhor" foi a mais antiga fórmula confessional da Igreja Primitiva (At 2,36; Rm 10,9; 1 Cor 11,23; 12,3; 16,22). Mas, o que é mais importante aqui é notar que esta confissão é cósmica em seu escopo, como observamos, e não confinado à Igreja: “ $\pi \tilde{\alpha} \sigma \alpha \gamma \lambda \tilde{\omega} \sigma \sigma \alpha /$ toda língua" é um modo poético para dizer “todos” e não apenas dos cristãos. Refere-se especialmente a "todas as pessoas" ou a todas as forças espirituais; desse modo, " $\gamma \lambda \tilde{\omega} \sigma \sigma \alpha /$ língua" é frequentemente usado como sinônimo

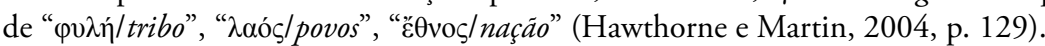


mesma atitude, mente (consciência) e os mesmos sentimentos de Cristo, para refletir a imagem de Deus também nas atitudes e nas relaçóes dentro e fora da comunidade cristã (Fee, 2004, p. 298; Focant, 2016, p. 160) ${ }^{23}$. A palavra " $\mu о \rho \varphi \tilde{n} /$ forma", presente no hino paulino, também pode evocar a imagem de Deus presente no primeiro homem do livro de Gênesis. Talvez exista uma contraposiçáo velada entre a figura de Cristo e a de Adão, e suas respectivas atitudes (Pastor, 2009, p. 76).

c) passemos agora ao estudo da última citação do AT feita por Paulo em Fl 2,15, que é uma alusão a Dt 32,5. Em Fl 2,15, dois artifícios chamam atenção. O primeiro é a alusão ao texto, a partir da LXX, do

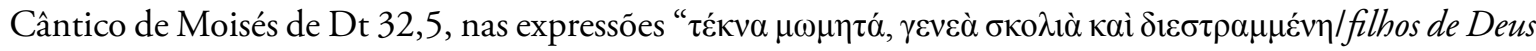
irrepreensiveis no meio de uma geração pervertida e corrupta”. E o segundo artifício é a expressão " $\varphi \alpha i ́ v \varepsilon \sigma \theta \varepsilon$

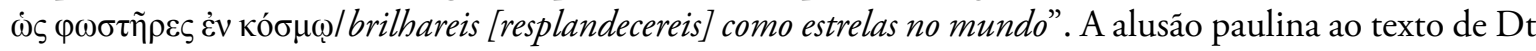

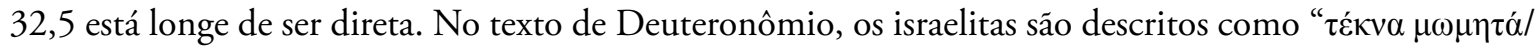

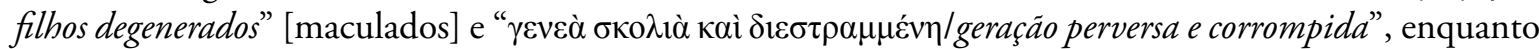
em Filipenses, Paulo oferece a seus leitores a possibilidade de se tornarem " $\tau \dot{\varepsilon} \kappa v \alpha$ ö $\mu \omega \mu \alpha /$ filhos inculpáveis", ou seja, "filhos sem mácula". A referência, no entanto, não é dos dias de Paulo, mas da história da geração do êxodo, que representa um aviso aos fiéis em Cristo, da comunidade dos filipenses (Holloway, 2017, p. 133-134; Craddock, 1985, p. 51) ${ }^{24}$.

\begin{tabular}{|c|c|c|c|}
\hline Fl 2,15 - NT & Tradução & Dt 32,5 - LXX & Comentário \\
\hline 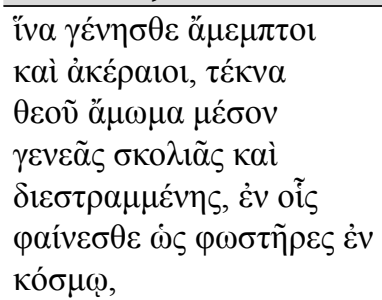 & $\begin{array}{l}\text { A fim de que vos torneis } \\
\text { irrepreensíveis e puros, } \\
\text { filhos de Deus inculpáveis } \\
\text { no meio de uma geraçáo } \\
\text { corrupta e pervertida, } \\
\text { entre os quais brilhareis } \\
\text { como luzeiros no mundo. }\end{array}$ & 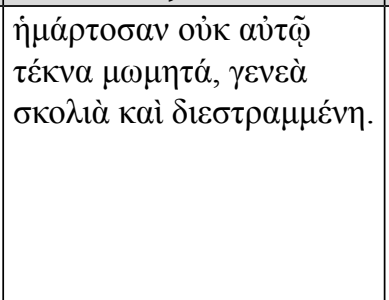 & $\begin{array}{l}\text { Aqui temos uma alusão } \\
\text { paulina feita ao texto de } \\
\text { Dt } 32,5 \text {, a fim de reforçar } \\
\text { a imagem de Cristo e de } \\
\text { sua própria imagem [de } \\
\text { Paulo] como modelos aos } \\
\text { cristãos filipenses. }\end{array}$ \\
\hline
\end{tabular}

23 Sobre este tema, indicamos também outras obras: Grappe, 2013, p. 19-39; Barbaglio, 1991, p. 375-380; Buscemi, 2000, p. 28-30; Hawthorne e Martin, 2004, p. 145; Holloway, 2017, p. 115-129; Mazzarolo, 2011, p. 83-87; Ueti, 2010, p. 62-68.

24 Várias são as obras que podemos conferir sobre esse tema, como: Hendriksen, 2005, p. 497-498; Fee, 2004 , p. $317-$ 318; Martin, 2011, p. 118-119; Pitta, 2010, p. 178; Reumann, 2008, p. 409-410. Para Holloway (2017, p. 134), esses israelitas antigos haviam sido considerados "maculados" e "uma geração torta e perversa". Paulo espera um conjunto oposto de resultados para os fiéis em Cristo. A alegoria que Paulo faz nessa leitura se refere a uma hermenêutica apocalíptica na qual descreve uma geração injusta condenada no fim dos dias; alegoria paulina descrita em 1 Cor 11,10 , e citada acima; visão confirmada por Hahn e De Boor, 2006, p. 220-221. Embora em Dt 32,5, os filhos de Israel

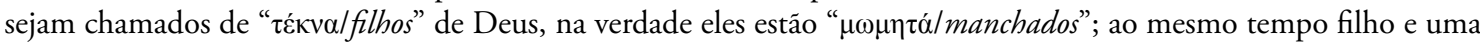

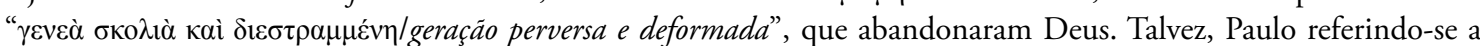
essas palavras do Deuteronômio, possa querer indicar duas coisas: (1) que a Igreja agora tem o privilégio de substituir Israel, ou melhor, restaurar Israel para seu verdadeiro destino, como "filhos de Deus", não como filhos culpados, mas como filhos sem culpa; e (2) insinuar entáo que Israel, perdeu esse privilégio por sua falta de humildade diante de Deus, e, consequentemente, não resta mais nada, a não ser se considerar como "geração perversa e deformada". $\mathrm{O}$

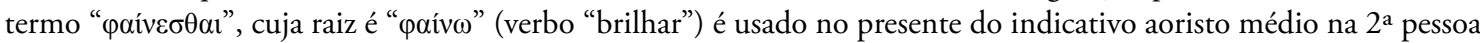
do plural, "brilhareis"; porém, o termo pode ser entendido no imperativo, isto é, "vós deveis brilhar". O contexto favorece essa interpretação. É improvável que Paulo esteja apenas lembrando aos filipenses o que eles já estão fazendo. Em vez disso, ele está novamente apelando para que os filipenses aceitem sua responsabilidade como filhos de Deus,

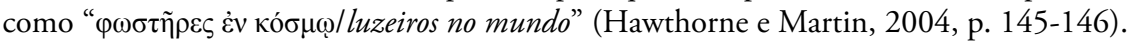


Em Fl 2,15, Paulo presentifica toda a temática e teologia do Êxodo. Desta vez, Paulo está procurando uma maneira de alcançar metas, tanto para os filipenses ( $F l$ 2,15) quanto para ele próprio (Fl 2,16). Se os filipenses se submetem à Lei de Deus "sem murmuraçóes nem queixas", eles terão como consequência

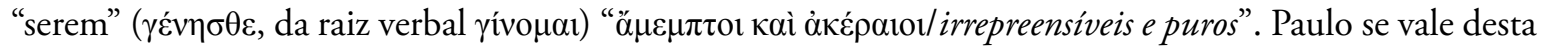
linguagem também em outras passagens para se referir ao status dos justos no julgamento final (1Ts 3,13; 5,23). Aqui, no entanto, o que está em vista é o comportamento cristão no presente e já pensando ao futuro. O Apóstolo está imaginando um processo de dois estágios no qual a condição futura daqueles que acreditam é determinada por sua transformação atual. Ele imagina um processo similar em Fl 1,11-12, onde ser encontrado "irrepreensivel e puro" no dia de Cristo depende de "ter sido preenchido" ( $\pi \varepsilon \pi \lambda \eta \rho \omega \mu \varepsilon ́ v o \mathrm{)})$ com o fruto da justiça nesta vida (Holloway, 2017, p. 133) 25 .

A linguagem de Paulo em Fl 2,15 também faz um eco quase idêntico ao texto de Dn 12,3, na versão

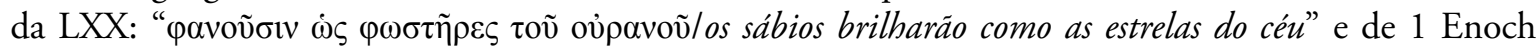

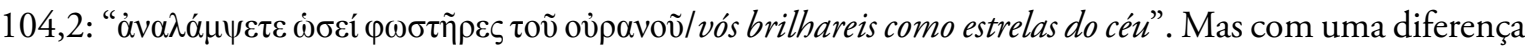
importante, a promessa em Daniel (também de 1 Enoch) fala de uma "angelificação" dos justos no mundo vindouro. Enquanto em Fl 2,15 a promessa é que os fiéis cristãos podem iniciar essa mesma experiência já

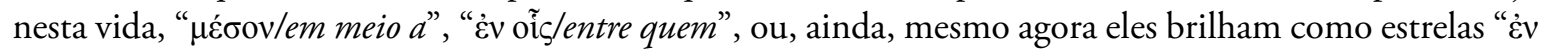

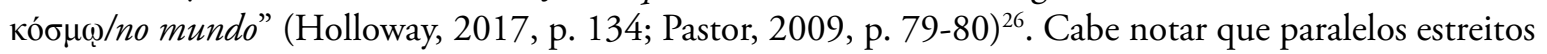
do texto de Dt 32,5, da versão da LXX, são encontrados em Mt 12,39 ("uma geração má e adúltera"), em Mt 17,17 (“ó, geração incrédula e perversa?") e em At 2,40 (“Salvai-vos desta geração perversa”). De modo semelhante, por serem " a luz do mundo" (Mt 5,14.16; Ef 5,8; 1Ts 5,5), estão constantemente proclamando seu redentor a um mundo confuso, injusto e cruel, em prol do Reino (Hendriksen, 2005, p. 499).

Sob os parâmetros da Análise Retórica, visto que Paulo usa muito a retórica em sua construção teológica (Aletti, 2011, p. 51), o v.15 se situa no trecho de Fl 2,12-18. O grande convite que perpassa esse texto é: "exerça sua cidadania de maneira digna do evangelho de Cristo" (Reumann, 2008, p. 405), e, nesse sentido, o que se pretende é tratar como os crentes se relacionam uns com os outros e com a politeia da

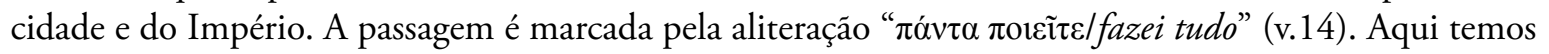

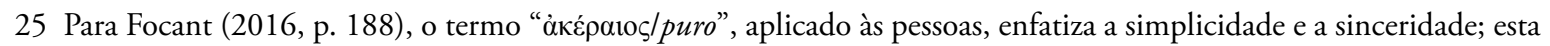
mesma ideia é defendida por Martin, 2011, p. 119. Para Mazzarolo (2011, p. 123), os cristáos, conhecedores de seu passado, não poderiam tomar os mesmos caminhos e seguir maus exemplos. Para Pitta (2010, p. 177-178), a conduta irrepreensível na Lei é de particular relevância ética enquanto alude à relação interna e externa na comunidade de Filipos.

26 Para Holloway (2017, p. 133), a linguagem aqui reflete algum entendimento de ressurreição, conforme é apresentada

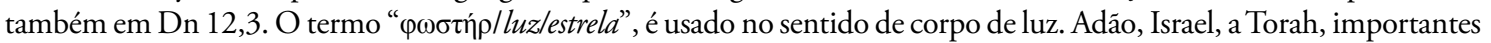
Rabis, foram chamados de "portadores da luz". As pessoas que compunham a comunidade de Qumran eram denominadas como "filhos da luz" (1QS I, 9; II, 16; 1QM XIII, 5,9; García Martínez, 1995, p. 46). Consequentemente, Paulo deve

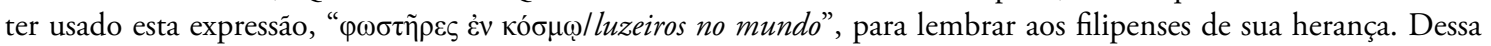
forma, os filipenses são considerados luzeiros ao realizar suas boas obras: harmonia, altruísmo, serviços aos outros, e entre outros. Assim sendo, esse brilhar não recai sobre si (ad intra), mas seria, isso sim, uma maneira de "brilhar para fora" (ad extra), para que, dessa forma, eles próprios influenciassem positivamente as pessoas ao seu redor. De qualquer forma, por mais que a frase seja entendida, é preciso ter presente o seguinte: Paulo não pretendia que suas palavras significassem apenas que os filipenses deveriam "se destacar" no contexto de sua sociedade. Assim como a luz dissipa as trevas, os cristãos devem dissipar as trevas do mal e da ignorância que estão por toda parte (Hawthorne e Martin, 2004, p. 146). 


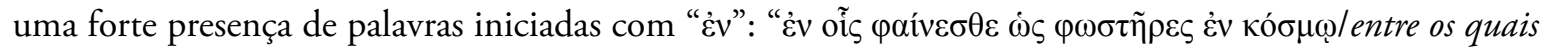
brilhais como luzeiros no mundo" (v.15). Além disso, ocorre a repetição por quatro vezes de "Eic": " $\lambda$ ó $\gamma o v$

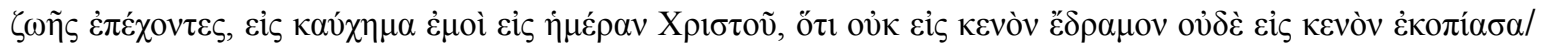
oferecendo a palavra da vida para o orgulho a mim para o dia de Cristo, que em vão náo corri nem em vão trabalhei" (v.16) (Reumann, 2008, p. 405-406).

\section{Conclusão}

Conforme proposto inicialmente, a partir das bibliografias que consideram o assunto, desenvolvemos neste artigo o uso do AT no NT, sobretudo, o uso do AT na Carta aos Filipenses, seja por meio de citaçóes, alusões ou ecos. Constatamos que na Carta aos Filipenses não temos citaçóes e sim alusôes ou ecos. Essa é uma prática comum nos diversos autores do NT, quase sempre a partir da versáo da LXX e não do Texto Hebraico, e em Filipenses não é diferente. Dessa forma, percebe-se o quanto esses hagiógrafos consideravam o AT como Escritura divina.

Conforme o uso paulino do AT no NT, verifica-se uma fundamentação sólida onde o Apóstolo dos Gentios $(\mathrm{Rm} 11,13)$ buscou respaldar sua abordagem à comunidade de Filipos. Por meio de alusóes ou ecos da intertextualidade veterotestamentária, Paulo quer transmitir confiança na intervenção divina diante dos desafios enfrentados, conforme os textos de Jó 13,16; alusão feita em Fl 1,19. Aqui vale a pena recordar que não é muito difícil estabelecer os limites entre alusões ou ecos, pois são implícitas e não explícitas como as citaçóes. Já o hino cristológico, mais especificamente o trecho de Fl 2,10-11, alude ou ecoa o texto do Servo sofredor de Is 45,23, no qual se reforça a identidade dos filipenses na busca de ânimo, a fim de que colocassem seus olhos em Cristo e seguissem seu modelo de entrega, amor e sacrifício na obediência à vontade do Pai e em prol do próximo. E o texto de Fl 2,15 alude ou ecoa Dt 32,5, também Dn 12,3 e o livro apócrifo de Enoch. O autor paulino busca desenvolver em seus leitores os propósitos e valores

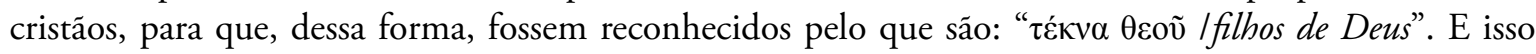
lhes serviria de exemplo na vida presente, enquanto ao final pudessem ter com ele a glória escatológica, já pensando ao futuro.

O desenvolvimento do presente estudo possibilitou uma análise de como o AT cumpriu papel fundamental a fim de que os filipenses adotassem os mesmos sentimentos de Cristo Jesus (Fl 2,5). Assim, com sua natureza convertida, digna do Evangelho de Cristo respaldada no exemplo paulino, suas vidas deveriam assumir um parâmetro ético que revelasse essa correspondência, onde o egoísmo, a vanglória, as quedas e as contendas estariam fora de qualquer cogitação.

Enfim, através da imagem da luz que brilha em meio às trevas fica esclarecida a relação Igreja-mundo. Dessa forma também se impóe uma perspectiva ética, na qual os fiéis são chamados a iluminar o mundo por meio de um testemunho de conduta íntegra. É a fidelidade prática ao anúncio evangélico que faz da Igreja um testemunho válido no meio do mundo (Barbaglio, 1991, p. 381-382). Ademais, todas as injunções que Paulo estabelece sobre os filipenses são para um propósito: para que (ivo) eles se tornem ( $\gamma \varepsilon \dot{\varepsilon} \eta\rceil \theta \varepsilon)$ pessoas melhores do que são. Se suas vidas são caracterizadas pela assertividade (غ̇pı $\theta \varepsilon i ́ \alpha)$, conceito

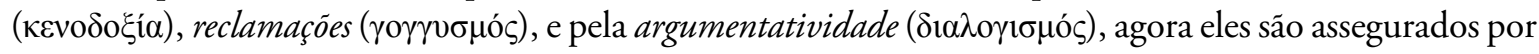


Paulo de que é possível e preciso melhorar ainda mais, em Jesus Cristo. Eles podem se tornar irrepreensiveis

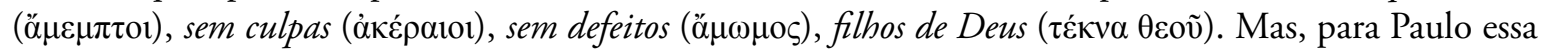
transformação só é possível quando há um desejo de resposta humanamente humilde e positiva às exigências

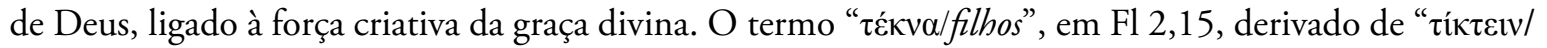
dar à luz", salienta a ideia de semelhança familiar, de compartilhar a natureza dos pais, neste caso, com Deus (Hawthorne e Martin, 2004, p. 144-145).

\section{Referências}

Aletti, J. N. (2011). Uma retórica paulina: construção e comunicação de um pensamento. Em A. Dettwiler, J-D. Kaestli, \& D. Margerat (Orgs.). Paulo, uma Teologia em construção (pp. 51-71). São Paulo: Loyola.

Barbaglio, G. (1991). As cartas de Paulo (II). São Paulo: Loyola.

Beale, G. K. (2013). Manual do uso do Antigo Testamento no Novo Testamento. São Paulo: Vida Nova.

Belli, F., Carbajosa, I., Estrella, C. J., Navarro, L. S., (2006). Vetus in Novo: El recurso a la Escritura en el Nuevo Testamento. Madrid: Encuentro.

Buscemi, A. M. (2000). Gli inni di Paolo: una sinfonia a Cristo Signore. Jerusalém: Franciscan Printing Press.

Craddock, F. B. (1985). Filippesi. Torino: Claudiana.

Elliger, K. e Rudolph, W. Bíblia Hebraica Stuttgartensia. Stuttgart: Deutsche Bibelgesellschaft, 1994.

Etcheverría, R. T. (2002). Estudios Paulinos. Salamanca: Publicaciones Universidad Pontificia Salamanca.

Fee, G. D. (2004). Comentario de la Epistola a los Filipenses. Barcelona: Clie.

Fitzmyer, J. A. (1988). The Aramaic Background of Philippians 2:6-11. Em CBQ (50), 470-483.

Focant, C. (2016). La Carta a los Filipenses. Salamanca: Sigueme.

García Martínez, F. (1995). Textos de Qumran. Edição fiel e completa dos Documentos do Mar Morto. Petrópolis: Vozes.

Gonzaga, W. (2017), O Corpus Paulinum no Cânon do Novo Testamento. Em Atualidade Teológica (v. 21, n. 55), 19-41. https://doi.org/10.17771/PUCRio.ATeo.29100

Gonzaga, W. (2019). Compêndio do Cânon Bíblico: Listas bilíngues dos Catálogos Bíblicos Antigo Testamento, Novo Testamento e Apócrifos. Petrópolis: Vozes.

Gonzaga. W. (2019a), "Nascido de Mulher” (Gl 4,4). Em Horizonte, Belo Horizonte, (v. 17 n. 53), 1194-1216.

Grappe, C. (2013). Aux sources de la christologie. Quelques remarques sur la structure les representations et l'originalité de 'lhymne de Philippiens 2,5-11 à la lumiére notamment de traditions vétérotestamentaires et juives. Em Arnold, M.; Dahan, G., \& Noblesse-Rocher, A., (Orgs). et al., Philippiens 2,5-11: La kénose du Christ. Paris: Cerf.

Haag, H. (1971). A formação da Sagrada Escritura. Em J. Feiner, \& M. Loehrer, Mysterium Salutis (vol. 1/2), 119156. Petrópolis: Vozes. 
Hahn, E., \& De Boor, W. (2006). Cartas aos Efésios, Filipenses e Colossenses: Comentário Esperança. Curitiba: Esperança.

Hawthorne, G. F. (2008). Carta aos Filipenses. Em G. F. Hawthorne, R. P. Martin, \& D. G. Reid (Orgs.). et al., Dicionário de Paulo e suas Cartas (pp. 556-564). São Paulo: Paulus/Vida Nova/Loyola.

Hawthorne, G. F., \& Martin, R. P. (2004). Philippians: Revised Edition. Michigan: Zondervan.

Hays, R. B. (1989). Echoes of Scripture in the Letters of Paul. Michigan: Yale University press.

Hendriksen, W. (2005). Efésios e Filipenses. São Paulo: Cultura Cristã.

Holloway, P. A. (2017). Philippians. Minneapolis: Fortress Press. https://doi.org/10.2307/j.ctt1tm7hgf

Kittel, R. (ed.). (1997). Biblia Hebraica Stuttgartensia. Editio quarta emendata opera H.P. Rüger. Stuttgart: Deutsche Bibelgesellschaft.

Martin, R. (2011). Filipenses: Introdução e comentário. São Paulo: Vida Nova.

Mazzarolo, I. (2011). Carta de Paulo aos Filipenses. Rio de Janeiro: Mazzarolo editor.

Meynet, R. (1993). A Análise Retórica. Um novo método para compreender a Bíblia. Em Brotéria (137), 391-408.

Meynet, R. (1996). I frutti dell'analisi retorica per l'esegesi biblica. En Gregorianum (77/3) 403-436.

Millos, S. P. (2016). Filipenses: Comentario exegético al texto griego del Nuevo Testamento. Barcelona: Clie.

Nestle-Aland. (2012). Novum Testamentum Graece. Ed. XXVIII. Stuttgart: Deutsche Bibelgesellschaft.

Murphy-O'Connor, J. (2006). Christological Anthropology in Phil II,6-11. Em RB (83), 25-50.

Pastor, F. (2009). Corpus Paulino II. Henao: Desclée De Brouwer.

Pitta, A. (2010). Lettera ai Filippesi: nuova versione, introduzione e commento. Milano: Paoline.

Rahlfs, A., \& Hanhart, R. (eds.). (2006). Septuaginta. Editio Altera. Stuttgart: Deutsche Bibelgesellschaft.

Reumann, J. (2008). Philippians: a new translation with introduction and commentary. London: Yale University.

Reumann, J. (2006). The (Greek) Old Testament in Philippians: 1:19 as Parade. Exemple - Allusion, Echo, Proverb. Em S. Son, History and Exegesis (pp. 189-200). New York: T\&TClark.

Robertson, A. W. (1996). El Antiguo Testamento en el Nuevo. Buenos Aires: Nueva creación.

Rodriguez, M. (2001). La Biblia Comentada por los Padres de la Iglesia y otros autores de la época patrística. Gálatas, Efesios, Filipenses. Nuevo Testamento, 8. Madrid: Ciudad Nueva.

Schnelle, U. (2014). Paulo, vida e pensamento. Santo André: Academia Cristá; São Paulo: Paulus.

Silva, M. (2008). Antigo Testamento em Paulo. Em G. F. Hawthorne, R. P. Martin, \& D. G. Reid (Orgs.). Dicionário de Paulo e suas Cartas. (2a ed.). (pp. 76-92). São Paulo: Vida Nova/Paulus/Ediçóes Loyola.

Ueti, P. (2010). No esvaziamento de Deus, a glória da vida. Uma leitura de Fl 2,5-11. Em Estudos Bíblicos (105), 57-75. 